\title{
The role of angiotensin II in the early stages of bovine ovulation
}

\author{
Rogério Ferreira, João Francisco Oliveira, Rafael Fernandes, José Ferrugem Moraes ${ }^{1}$ and \\ Paulo Bayard Gonçalves
}

Laboratory of Biotechnology and Animal Reproduction, BioRep, Federal University of Santa Maria, 97105-900 Santa Maria, Rio Grande do Sul, Brazil and ' EMBRAPA Pecuária Sul, 96401-970 Bagé, Rio Grande do Sul, Brazil

Correspondence should be addressed to P B Gonçalves who is now at Departamento de Clínica de Grandes Animais, Hospital Veterinário, Universidade Federal de Santa Maria, 97105-900 Santa Maria, Rio Grande do Sul, Brazil;

Email: bayard@biorep.ufsm.br

\begin{abstract}
There is evidence that the renin-angiotensin system plays an important role in ovulation in cattle. Using an in vivo model, we investigated the role of angiotensin (Ang) II in bovine ovulation by injecting Ang II receptor antagonists into ovulatory follicles. Animals (n=102) were pre-synchronized and, when the follicles reached $12 \mathrm{~mm}$, they were given the respective treatment and the cows received GnRH agonist (i.m.) to induce ovulation. The ovulation rate was significantly lower when $100 \mu \mathrm{M}$ saralasin (Ang II receptor antagonist) was intrafollicularly injected $(\mathbf{1 4 . 3} \%)$ in comparison with saline solution $(\mathbf{8 3 . 3} \%)$. Based on these results, a second experiment was carried out to determine the timing of Ang II's critical role in ovulation. Saralasin inhibited ovulation only when applied at 0 and $6 \mathrm{~h}$ (16.7 and $\mathbf{4 2 . 9} \%$ ovulation rate in the 0 - and 6-h groups respectively), but not at $12 \mathrm{~h}(\mathbf{1 0 0} \%)$ following GnRH agonist treatment. To investigate the

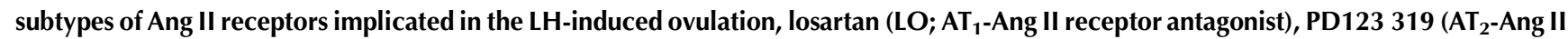
receptor antagonist), LO+PD123 319, or saline were intrafollicularly injected when the cows were challenged with GnRH agonist.

Ovulation was inhibited by PD123 319 and LO+PD123 319 (50.0 and 33.3\% on ovulation rate respectively), but not by LO or saline solution (100\% ovulation in both groups). From these results, we suggest that Ang II plays a pivotal role in the early mechanism of bovine ovulation via the $\mathrm{AT}_{2}$ receptor subtype.

Reproduction (2007) 134 713-719
\end{abstract}

\section{Introduction}

Ovulation is dependent on adequate luteinizing hormone $(\mathrm{LH})$ release, which activates several established components of the ovulatory cascade (Espey 1980, Robker et al. 2000). The understanding of ovulatory pathways can be considered a new approach for infertility treatment and control ovulation in mammals (i.e. non-steroid contraceptives for women and bitches, and estrous cycle control in cows). However, the intrafollicular factors that initiate and control the ovulatory process are not well understood. Cyclooxygenase-2 has been identified as the key player that initiates the cascade of proteolytic activity required for tissue remodeling process during ovulation (Sirois 1994, Sirois \& Dore 1997, Robker et al. 2000, Peters et al. 2004). In some tissues, Ang II induces an increase in expression of cyclooxygenase-2 and prostaglandins (Gimbrone \& Wayne Alexander 1975, Hernández et al. 2002, Scheuren et al. 2002, Kim et al. 2005). The action of Ang II in the ovulatory process appears to differ between some species. Using an in vitro model, Yoshimura et al. (1993) showed that Ang II plays an essential role in inducing prostaglandin production during ovulation in the rabbit. However, Husain et al. (1987) did not find the expected autoradiographic distribution of Ang II receptors in every developing follicle, suggesting that not all preovulatory follicles necessarily respond to exogenous or endogenous Ang II in the rat. Also in the rat ovary, Ang II receptors were not detected in preovulatory follicles with $\mathrm{LH}$ receptors (Daud et al. 1989). Using the microdialysis technique, Acosta et al. (2000) demonstrated that Ang II has a role in angiogenesis during ovulation, formation of the corpus luteum, and luteolysis in cattle. In addition to its vascular action, it was demonstrated that Ang II induces prostaglandin production in the rabbit ovary (Yoshimura et al. 1992, Kuji et al. 1996). Additionally, Ang II activity has been related to oocyte maturation, ovulation, and steroidogenesis in the rabbit (Yoshimura et al. 1992, 1993, Feral et al. 1995, Tanaka et al. 1995, Hayashi et al. 2000) and associated with resumption of meiosis (Giometti et al. 2005, Stefanello et al. 2006), steroidogenesis (Acosta et al. 1999), and follicular growth (Nielsen et al. 1994, Portela et al. 2006) in cattle.

At least two Ang II receptor subtypes, $\mathrm{AT}_{1}$ and $\mathrm{AT}_{2}$, have been identified and characterized (Bottari et al. 1993, DeGasparo et al. 1995, Gallinat et al. 2000). The 
$\mathrm{AT}_{1}$ receptor mediates a number of well-known Ang II effects on smooth muscle contraction, aldosterone secretion, and blood pressure regulation, while the $\mathrm{AT}_{2}$ receptor has been shown to mediate the opposite effects and induce apoptosis (Yamada et al. 1996) and reproductive functions, including steroidogenesis, oocyte maturation, and ovulation (Kuji et al. 1996, Yoshimura et al. 1996). Yoshimura et al. (1996) inhibited ovulation using a specific $\mathrm{AT}_{2}$ inhibitor (PD123 319) in rabbit ovaries perfused in vitro, but not using CV-11 974, a specific inhibitor of $\mathrm{AT}_{1}$ receptors. PD123 319 is an $\mathrm{AT}_{2}$ receptor antagonist with low affinity for $A T_{1}$ receptors, and specifically inhibits binding of Ang II at a concentration of $100 \mu \mathrm{M}$ (Yoshimura et al. 1996). Losartan (LO) is a antagonist of $\mathrm{AT}_{1}$ receptors with low affinity for $\mathrm{AT}_{2}$ receptors (Chiu et al. 1989, Whitebread et al. 1989) and is of great therapeutic value for the control of blood pressure. In cattle, Ang II type 2 receptor was identified mainly in the dominant follicle by autoradiograms (Schauser et al. 2001), and its expression was positively correlated with follicular diameter (Nielsen et al. 1994). Recently, our group demonstrated that expression of $\mathrm{AT}_{2} \mathrm{mRNA}$ in granulosa cells is correlated with follicle health and estradiol content and is regulated by follicle-stimulating hormone (FSH), insulin-like growth factor-I, bone morphogenetic protein-7, fibroblast growth factor (FGF-7), and FGF-10 (Portela et al. 2006, Portela et al. 2007). We also showed that Ang II regulates protease nexin-1 (PN-1; inhibitor of proteases involved in extracellular matrix remodeling and follicle rupture) in granulosa cells via $\mathrm{AT}_{2}$ receptor in cattle (Portela et al. 2006).

Since the requirement for Ang II in the ovulatory process is species specific and the in vitro receptor expression studies do not provide conclusive evidence that Ang II is essential for ovulation to occur, we designed experiments to investigate the hypothesis that Ang II is required to initiate the ovulatory process in cattle. The requirement for Ang II for the ovulatory process and the receptor subtype were investigated using an in vivo model. Specific inhibitors of Ang II receptors were injected into ovulatory follicles by an ultrasoundguided intrafollicular injection system to manipulate the follicular environment in cattle.

\section{Results}

\section{Effect of Ang II receptor antagonist on ovulation}

The first experiment was conducted to assess the role of Ang II in ovulation. Follicles that received saline ovulated at significantly higher rates $(88.9 \%$; 8 out of 9$)$ when compared with those treated with saralasin (Ang II receptor antagonist; $38.5 \%$; 5 out of $13 ; P<0.0342$; Fig. 1) after challenging the cows with gonadotropinreleasing hormone $(\mathrm{GnRH})$ agonist. Nine cows (9 out of 22) were detected in estrus when treatments were applied. In the absence of estrus, the ovulation rates were $14 \%$ ( 1 out of 7 ) and $83 \%$ (5 out of 6 ) in the saralasin and control groups respectively $\left(\chi^{2}=4.89,1\right.$ d.f., $P<0.05$; Fig. 1). However, there was no difference in the ovulation rates when saline $(100 \% ; 3$ out of 3$)$ and saralasin $(67 \% ; 4$ out of 6$)$ were injected during estrus $\left(\chi^{2}=0.08,1\right.$ d.f., $P>0.05$; Fig. 1$)$. There was no difference between the mean diameters of the follicles injected with saralasin $(13.0 \pm 0.39 \mathrm{~mm})$ and saline $(13.7 \pm 0.82 \mathrm{~mm}$, $P>0.05)$. In addition, the mean diameter of the injected follicle was not different in cows that ovulated $(13.7 \pm 0.63 \mathrm{~mm})$ when compared with those that did not ovulate (12.7 $\pm 0.32 \mathrm{~mm} ; P>0.05)$.

\section{Effect of Ang II receptor antagonist during the process of ovulation}

In order to evaluate whether Ang II is only a prerequisite for initiating the cascade of events or for the whole process that ultimately leads to ovulation, saralasin was intrafollicularly injected at 0,6 , and $12 \mathrm{~h}$ after $\mathrm{GnRH}$ challenge. The ovulation blocking effect of saralasin occurred when applied at $0 \mathrm{~h}(16.7 \%, 1$ out of 6 ; $\chi^{2}=19.6,1$ d.f., $\left.P<0.0001\right)$ and 6 h $(42.9 \%, 3$ out of 7 ; $\chi^{2}=61.8,1$ d.f., $\left.P<0.0001\right)$, but not at $12 \mathrm{~h}(100 \%, 7$ out of 7). There was no significant difference between the first two groups $\left(\chi^{2}=0.98,1\right.$ d.f., $P>0.05$; Fig. 2$)$. The follicular diameter (mean \pm s.E.M.) was not different at the time of intrafollicular injection at $0 \mathrm{~h}(12.8 \pm$ $0.41 \mathrm{~mm}), 6 \mathrm{~h}(13.9 \pm 0.60 \mathrm{~mm})$, and $12 \mathrm{~h}(14.3 \pm$

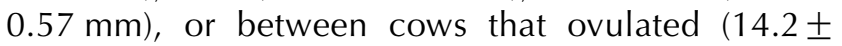
$0.48 \mathrm{~mm}$ ) when compared with those that did not ovulate $(13.1 \pm 0.37 \mathrm{~mm} ; P>0.05)$.

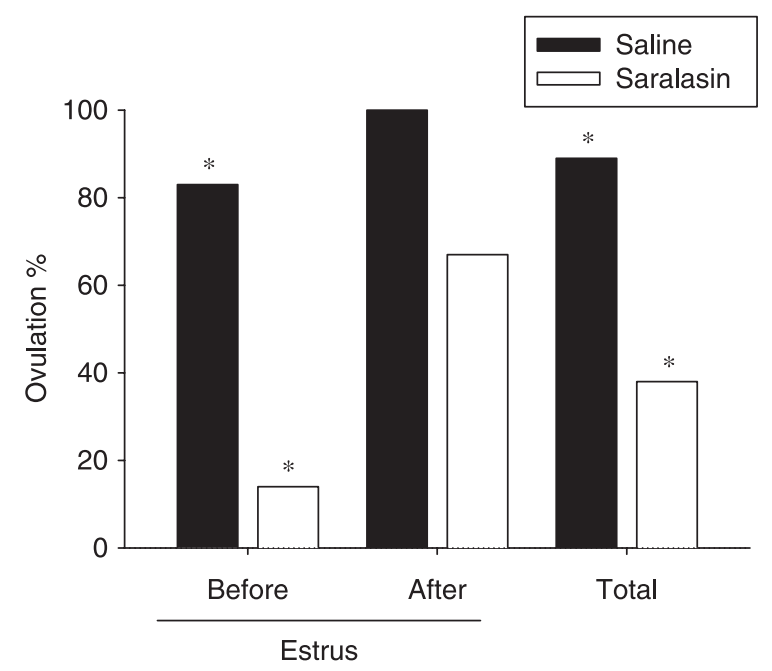

Figure 1 Ovulation rate following ultrasound-mediated intrafollicular injection of an angiotensin II receptor antagonist (saralasin) in cows. When the follicles reached $12 \mathrm{~mm}$, they were given the respective treatment and the cows received $\mathrm{GnRH}$ agonist $(100 \mu \mathrm{g}$ gonadorelin acetate, i.m.) to induce ovulation. The cows were randomly chosen to receive an intrafollicular injection of saralasin (saralasin group, $n=13$ ) or $\mathrm{NaCl} 0.9 \%$ solution (saline group, $n=9)$ before $(n=13)$ or after $(n=9)$ the onset of estrus. * Statistical difference between groups $(P<0.05)$. 


\section{Effect of $A T_{1}$ and $A T_{2}$ receptor antagonists on ovulation rate}

The effect of Ang II receptor antagonists was assessed by intrafollicular injection of the Ang II type 1 receptor antagonist LO (DUP, 753) and/or type 2 receptor antagonist PD123 319. Ovulation rate was significantly reduced by PD123 $319(P<0.0001)$, but not by LO (Fig. 3). A similar reduction in ovulation rate was observed when both LO and PD123 319 were applied to the same follicle. The diameters of the largest follicle (mean \pm S.E.M.) when the antagonists were intrafollicularly injected were $13.1 \pm 0.20,13.0 \pm 0.30,12.8 \pm 0.29$, and $13.0 \pm 0.13 \mathrm{~mm}$ in the treatment $(\mathrm{LO}, \mathrm{PD}$, and $\mathrm{LO}+\mathrm{PD})$ and control groups respectively $(P>0.05)$. The follicular diameters were not different in cows that ovulated $(13.1 \pm 0.12 \mathrm{~mm})$ when compared with those that did not ovulate $(12.7 \pm 0.24 \mathrm{~mm} ; P>0.05)$.

\section{Discussion}

The present studies tested the hypothesis that Ang II is required for initiating the ovulatory process. Our significant findings are: (1) the ovulation rate decreased when saralasin (Ang II receptor antagonist) was administered before estrus onset and (2) within a few hours after challenge with $\mathrm{GnRH}$ agonist; (3) the ovulation rate was reduced following the intrafollicular injection of the AT2 receptor antagonist (PD123 319), but not after AT1 receptor antagonist $(\mathrm{LO})$ treatment. The present results provide strong evidence that Ang II is involved in initiating the ovulatory cascade by activating the AT2 receptor. These findings complement an earlier study, which demonstrated an increase in Ang II concentration in follicular fluid

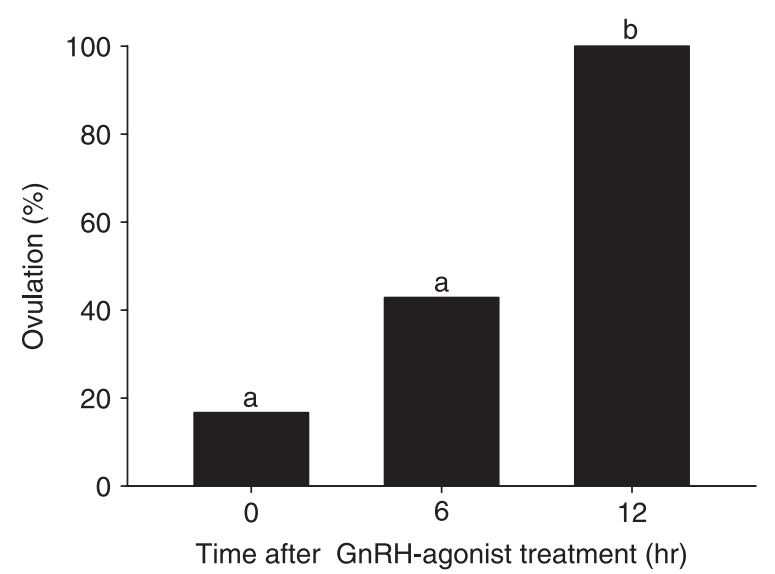

Figure 2 Ovulation rate following ultrasound-mediated intrafollicular injection of an angiotensin II receptor antagonist (saralasin) at 0, 6, or $12 \mathrm{~h}$ after $\mathrm{GnRH}$ agonist challenge (100 $\mu$ g gonadorelin acetate, i.m). The cows $(n=20)$ had follicular diameter of at least $12 \mathrm{~mm}$ at intrafollicular injection. Different letters above bars indicate statistical difference between groups $(P<0.05)$.

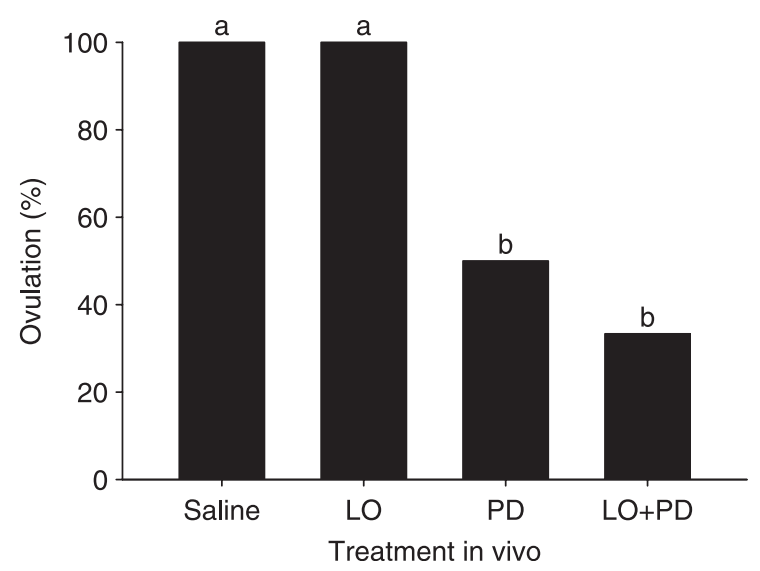

Figure 3 Effect of angiotensin II type 1 (AT1) and type 2 (AT2) receptor antagonists on ovulation rate in cow. When the follicular diameter reached at least $12 \mathrm{~mm}$, they were given the respective treatment and the cows received a $\mathrm{GnRH}$ agonist (100 $\mu$ g gonadorelin acetate, i.m.) to induce ovulation. The animals received an ultrasound-mediated intrafollicular injection of $0.9 \% \mathrm{NaCl}$ (saline, $n=6$ ), losartan (LO, $10 \mu \mathrm{M}$; AT1 receptor antagonist; $n=6$ ), PD123 319 (PD, $10 \mu \mathrm{M}$; AT2 receptor antagonist; $n=6)$, or $10 \mu \mathrm{M} \mathrm{LO}+10 \mu \mathrm{M} \mathrm{PD}(n=6)$. Different letters above bars indicate statistical difference between groups $(P<0.05)$.

concomitantly with the onset of ovulation after the ovulatory LH surge (Acosta et al. 2000).

In this study, saralasin was used as a potent Ang II antagonist that blocks all known receptor subtypes (Kuji et al. 1996, Yoshimura et al. 1996). The saralasin concentration of $10 \mu \mathrm{M}$ used in this experiment inhibits binding of Ang II to its receptors (Kuji et al. 1996). Saralasin does not appear to be toxic in follicular cells, since cows that received a sequential FSH treatment and intrafollicular injection of saralasin in $7 \mathrm{~mm}$ follicles displayed follicular growth and ovulated (unpublished data). The high ovulation rate $(67 \%)$, observed when saralasin was injected intrafollicularly after the onset of estrus, also rules out a possible toxic effect of saralasin on follicular cells. In addition, this peptide has been widely used to block the effect of the renin-Ang system or to study the action of Ang II, showing a high specificity for its receptors (Kuji et al. 1996, Yoshimura et al. 1996, Camargo \& Saad 1999).

The exclusion of animals that did not meet the criteria of a minimum follicular diameter $(12 \mathrm{~mm})$ was based on the high ovulation rate of follicles larger than $12 \mathrm{~mm}$ obtained after LH exposure (Sartori et al. 2001). The high ovulation rate obtained in the control groups (14 out of 15 animals, 93\%) demonstrates that the possible damage caused by the intrafollicular injection technique was not significant for final follicular development or ovulation, similar to other studies (Kot et al. 1995, Ginther et al. 2004). The success rate of the intrafollicular injection technique was $81.5 \%$ ( 66 out of 81 animals), similar to those previously reported (Kot et al. 1995, Ginther et al. 2004). Our results provide 
further evidence that the ultrasound-guided intrafollicular injection system is a effective method to investigate the role of Ang II in the ovulatory process in cattle and supports previous studies demonstrating a physiological function of this peptide by i.p. injection in rabbits (Pellicer et al. 1988).

Interestingly, ovulation was inhibited when saralasin was intrafollicularly injected at the same time as GnRH treatment, but, in contrast, all follicles that received saralasin $12 \mathrm{~h}$ after $\mathrm{GnRH}$ treatment reached ovulation. These results indicate that Ang II has a role in the early stages of the ovulatory cascade. Further, Ang II induced ovulation in in vitro perfused rabbit ovaries, and its levels increased in follicular fluid after exposure to gonadotropins, suggesting an intrafollicular increase in renin-like activity in initiating the ovulatory process (Yoshimura et al. 1994). In cows, the levels of Ang II increase after $\mathrm{LH}$ surge and remain elevated throughout the ovulatory process (Acosta et al. 2000), and as such Ang II seems to be a key determinant in the ovulatory process. It could be speculated that Ang II triggers cyclooxygenase-2 to initiate the ovulatory process, which is a feasible ovulatory event that might lead to ovulation (Sirois 1994, Sirois \& Dore 1997, Peters et al. 2004). Yoshimura et al. (1993) demonstrated that Ang II may induce ovulation in the rabbit ovary, at least in part, by stimulation of prostaglandin production.

The results from the current study suggest that Ang II acts through $\mathrm{AT}_{2}$ receptor to stimulate the ovulatory process. A specific $\mathrm{AT}_{2}$ receptor antagonist PD123 319 inhibited ovulation independently of the presence of the $\mathrm{AT}_{1}$ receptor antagonist $\mathrm{LO}$ in this study. Saralasin inhibited ovulation nearly $100 \%$ and, in the third experiment, $\sim 30 \%$ of follicles ovulated when the AT2 receptor inhibitor (PD123 319) was used. These findings are in accordance with a competition assay described by Yoshimura et al. (1996), where saralasin inhibited specific binding of Ang II in a concentration-dependent manner, reaching $100 \%$ inhibition at $10^{-7} \mathrm{M}$, while specific inhibitors of Ang II receptors do not completely inhibit Ang II binding even at $10^{-4} \mathrm{M}$. We showed for the first time that intrafollicular injection of $\mathrm{AT}_{2}$, but not $\mathrm{AT}_{1}$, receptor antagonist in vivo inhibited ovulation in cattle. We are aware that the characterization of Ang II receptor subtype in bovine ovarian follicles has been described (Schauser et al. 2001); however, our findings provide additional support to in vitro studies, showing $\mathrm{AT}_{2}$ receptor function in vivo. In rabbits, Yoshimura et al. (1996) induced ovulation and oocyte maturation in ovaries with Ang II via the $\mathrm{AT}_{2}$ receptor subtype and inhibited ovulation with PD123 319 administration but not with CV-11 974, a specific inhibitor of $\mathrm{AT}_{1}$ receptors. In the present study, PD123 319 was used because of its high affinity for $\mathrm{AT}_{2}$ receptors, and the concentration used in this experiment $(100 \mu \mathrm{M})$ caused complete inhibition of specific Ang II binding to $\mathrm{AT}_{2}$ receptor in rabbit ovaries (Kuji et al. 1996). Taken together, these data suggest that Ang II plays an important role in the ovulatory cascade via $\mathrm{AT}_{2}$ receptors in cattle.

We recognize that we cannot exclusively attribute the effects of Ang II on the ovulatory cascade using the ultrasound-guided intrafollicular injection approach. However, we have previously demonstrated that $\mathrm{AT}_{2}$ receptor mRNA levels are significantly higher in granulosa cells of estrogenic follicles when compared with non-estrogenic follicles, and $\mathrm{AT}_{2}$ receptor mRNA is correlated with estradiol concentrations in follicular fluid (Portela et al. 2006). In addition, Ang II inhibits $\mathrm{PN}-1$ expression, an inhibitor of proteases involved in extracellular matrix remodeling and follicle rupture, providing evidence that Ang II can regulate ovulation (Portela et al. 2006). Moreover, oocyte maturation, which is an event that occurs just before ovulation and after the LH surge, is mediated by Ang II (Giometti et al. 2005, Stefanello et al. 2006). Studies with laboratory animal species also support these results. Ovulation is inhibited by the administration of saralasin to in vitro perfused rabbit ovaries (Yoshimura et al. 1993). However, in rat, Ang II receptors were not detected in every developing follicle (Husain et al. 1987) and in preovulatory follicles with LH receptors (Daud et al. 1989), suggesting a species-specific effect of Ang II on ovulation.

Cattle provide an excellent model for studying the ovulatory process, since the follicular environment can be easily modified by ultrasound-guided intrafollicular injection (Kot et al. 1995, Ginther et al. 2004) and accurately monitored on a day-to-day basis by ultrasonography in vivo (Savio et al. 1988, Ginther et al. 1989, Evans \& Fortune 1997). Using this in vivo model, we demonstrated that Ang II is essential for ovulation in cattle, since inhibition of Ang II by intrafollicular injection of saralasin led to inhibition of ovulation. These results also provide strong evidence that Ang II has a role in the early stages of the ovulatory cascade, acting as a key factor in the ovulatory process through the $\mathrm{AT}_{2}$ receptor.

\section{Materials and Methods}

\section{Inhibitors, hormones and supplies}

The Ang II receptor antagonists, saralasin and PD123 319, were purchased from Sigma and LO (DuP 753) from Du Pont Merck Pharmaceutical Company. The ultrasound system, including scanner (Pie Medical Scanner 200) probes, biopsy, and needle guide, was provided by Pie Medical Equipment BV (Maastricht, The Netherlands). The controlled internal drug release (CIDR) devices were acquired from InterAg (Hamilton, New Zealand), estradiol benzoate from Genix (Anápolis, Brazil), sodium cloprostenol from Ouro Fino (Ribeirão Preto, Brazil), and equine chorionic gonadotropin (eCG) was from Syntex (Buenos Aires, Argentina). The GnRH agonist gonadorelin acetate was purchased from Tortuga (São Paulo, Brazil). The intrafollicular injection system needles were acquired from Becton, 
Dickinson and Company (Franklin Lakes, NJ, USA). The Hamilton syringe was purchased from Sigma.

\section{Animals and sequential ultrasound scanning}

All experimental procedures using cattle were reviewed and approved by the Federal University of Santa Maria Animal Care and Use Committee (ACUC). One hundred and two cycling, non-lactating, mature Hereford cows with a body condition score of 3 or 4 (scale from 1-thin to 5-obese) were presynchronized with CIDR (the insertion of the vaginal device was defined as day 0 ) for 9 days, estradiol benzoate ( $5 \mathrm{mg}$, i.m., on day 0$)$, sodium cloprostenol (125 $\mu$ g, s.c., on day 6$)$, and eCG (400 IU, i.m., on day 6). After CIDR device removal, the cows were checked twice a day for estrus behavior. Follicular growth was monitored daily through transvaginal ultrasonography by a single operator using an ultrasound equipped with a sectorial $7.5 \mathrm{MHz}$ transducer. Only cows that reached a minimum follicular diameter of $12 \mathrm{~mm}$ after CIDR device removal were included in this study $(n=81)$.

\section{Ultrasound-guided intrafollicular injection procedures}

The intrafollicular injections were guided by ultrasound equipped with a $7.5 \mathrm{MHz}$ vaginal probe. A system with two sterile needles was adapted from Kot et al. (1995). The doublechanneled needle system consisted of an inner sterile 25-gage needle attached to $35 \mathrm{~cm}$ long cannula and an outer 20-gage needle coupled to a needle guide. To the opposite end of the cannula, a Hamilton syringe was attached. Epidural anesthesia was induced, and perineal cleaning was performed before injections. The transducer was coupled to a biopsy guide (Pie Medical Equipment BV), coated with lubricant, and placed in the vaginal fornix. The course of the echogenic needle was observed on the ultrasound display, which allowed us to reach the follicle of interest. The ovary was manipulated so that the needle entered the follicle via penetration of the ovarian stroma at the base of the follicle. The needle path to the injected follicle contained ovarian stroma and no additional follicles or corpus luteum.

Immediately before injection, the inner needle system was washed consecutively with $70 \%$ alcohol and sterile $0.9 \% \mathrm{NaCl}$ solution and filled with appropriate treatments, and the system was set-up. When the ovary and follicle of interest were in position, the outer needle was advanced until the image of its tip became visible on the screen, $\sim 1 \mathrm{~cm}$ from the follicle. At this moment, a second operator pushed the inner needle forward until the image of the needle tip was visible within the follicle. Treatments were then injected into the follicle. Swirling of the fluid entering the follicle indicated that the injection was successful. The amount of Ang II receptor antagonists for the injection was calculated based on the volume of follicular fluid to obtain an adequate final concentration inside the follicle. The follicular fluid volume was estimated by the linear regression equation $V=-685.1+120.7 D(P=0.0001)$, determined in a pre-experiment, where $V$ corresponds to the estimated follicular volume and $D$ to the diameter of the follicle to be injected. The probe and needles were withdrawn immediately after injection to minimize pressure on the newly punctured follicle. Follicular diameter was measured again $2 \mathrm{~h}$ after intrafollicular injection. Cows were excluded from the experiment if the reduction in follicular diameter was $>2 \mathrm{~mm}$.

\section{Experiment 1: effect of angiotensin II (Ang II) receptor antagonist on ovulation}

Twenty-five cows were randomly assigned to two groups to receive an intrafollicular injection of $100 \mu \mathrm{M}$ saralasin (a potent Ang II inhibitor that blocks all known Ang II-receptor subtypes; saralasin treatment group; $n=13$ ) or $0.9 \% \mathrm{NaCl}$ (saline control group; $n=12$ ). The follicles were intrafollicularly injected when they reached the size of $12 \mathrm{~mm}$. The amount of saline and saralasin for the injection was calculated as described above, to obtain a final concentration of $10 \mu \mathrm{M}$ saralasin inside the follicle. The experiment was performed in two replicates (10-15 cows per replicate). Three cows were discarded from the control group because the follicular diameter was reduced by more than $2 \mathrm{~mm}$ after intrafollicular injection. The cows were challenged with $\mathrm{GnRH}$ agonist (100 $\mu \mathrm{g}$ gonadorelin acetate, i.m.) just after intrafollicular injections. The injected follicle was monitored by ultrasound examination every $24 \mathrm{~h}$ until ovulation or atresia. Ovulation was presumed when the treated follicle was not present between two assessments, and the corpus luteum was subsequently formed. The absence of ovulation for a period of $48 \mathrm{~h}$, associated with a gradual decrease in follicular diameter, was characterized as follicular atresia.

\section{Experiment 2: effect of Ang II receptor antagonist during the process of ovulation}

Twenty-five cows were randomly assigned to three groups to receive an intrafollicular injection of $100 \mu \mathrm{M}$ saralasin (saralasin treatment group) under similar conditions as in the previous experiment. The volume of saralasin to be injected was estimated as described above. The cows received saralasin at 0 ( 0 h group; $n=6$ ), 6 (6 h group; $n=7$ ), or $12 \mathrm{~h}$ (12 h group; $n=7)$ following GnRH agonist injection. The 'time $0^{\prime}$ was considered when the follicles reached $12 \mathrm{~mm}$. The experiment was performed in three replicates (seven to ten cows per replicate). The injected follicle was monitored by ultrasound examination every $24 \mathrm{~h}$ until ovulation or atresia, as described in the first experiment. Five cows were discarded from the experiment because the follicular diameter was reduced by more than $2 \mathrm{~mm}$ after intrafollicular injection.

\section{Experiment 3: effect of $A T 1$ and $A T 2$ receptor antagonists on ovulation rate}

Thirty-one cows divided into four groups were treated with $\mathrm{GnRH}$ agonist (100 $\mu$ g gonadorelin acetate, i.m.) and randomized in a $2 \times 2$ factorial design: intrafollicular injection of $100 \mu \mathrm{M}$ (LO group; specific inhibitor of $\mathrm{AT}_{1}$ receptors), $100 \mu \mathrm{M}$ PD123 319 (PD group; inhibitor of $\mathrm{AT}_{2}$ receptors), $100 \mu \mathrm{M}$ PD123 319+100 $\mu \mathrm{M}$ LO (PD+LO group), or $0.9 \% \mathrm{NaCl}$ (saline group). The moment of intrafollicular injection was determined when the follicle reached $12 \mathrm{~mm}$, and the four 
treatments were tested in three replicates. The injected volume was based on the follicular fluid volume (estimated as described above) to obtain a final concentration of $10 \mu \mathrm{M}$ of each inhibitor. Seven cows were discarded from the experiment because the follicular diameter was reduced by more than $2 \mathrm{~mm}$ after intrafollicular injection.

\section{Statistical analysis}

Validation of the results for the three experiments was performed by analysis of variance of follicular diameter at the time of treatment using the class variables treatment, ovulation, and treatment versus ovulation interaction as factors. The ovulation rate was compared between the different treatments in a statistical model for categorical variables using PROC CATMOD (Categorical Data Analysis Procedures), and differences between groups were analyzed by contrasts. All analyses were performed with the SAS statistical program (SAS Institute, Cary, NC, USA) with the level of significance set at $5 \%$.

\section{Acknowledgements}

The authors would like to thank Mr Walter $\mathrm{N}$ Ferreira for providing the animals used in this work. The authors declare that there is no conflict of interest that would prejudice the impartiality of this scientific work.

\section{References}

Acosta TJ, Berisha B, Ozawa T, Sato K, Schams D \& Miyamoto A 1999 Evidence for a local endothelin-angiotensin-atrial natriuretic peptide systemin bovine mature follicles in vitro: effects on steroid hormones and prostaglandin secretion. Biology of Reproduction 61 1419-1425.

Acosta TJ, Ozawa T, Kobayashi S, Hayashi K, Ohtani M, Kraetzl WD, Sato K, Schams D \& Miyamoto A 2000 Periovulatory changes in the local release of vasoactive peptides, prostaglandin F2alpha, and steroid hormones from bovine mature follicles in vivo. Biology of Reproduction 63 1253-1261.

Bottari SP, de Gasparo M, Steckelings UM \& Levens NR 1993 Angiotensin receptor II, subtypes: characterization, signalling mechanisms, and possible physiological implications. Frontiers in Neuroendocrinology 14 123-171.

Camargo LADA \& Saad WA 1999 Renal effects of angiotensin II receptor subtype 1 and 2 -selective ligands injected into the paraventricular nucleus of conscious rats. Regulatory Peptides 84 91-96.

Chiu AT, Herblin WF, McCall DE, Ardecky RJ, Carini DJ, Duncia JV, Pease LJ, Wong PC, Wexler RR, Johnson AL et al. 1989 Identification of angiotensin II receptor subtypes. Biochemical and Biophysical Research Communications 165 196-203.

Daud AI, Bumpus FM \& Husain A 1989 Angiotensin-II - does it have a direct obligate role in ovulation? Science 245 870-871.

DeGasparo M, Husain A, Alexander W, Catt KJ, Chiu AT, Drew M, Goodfriend T, Harding JW, Inagami T \& Timmermans PB 1995 Proposed update of angiotensin receptor nomenclature. Hypertension $\mathbf{2 5}$ 924-927.

Espey LL 1980 Ovulation as an inflammatory reaction - a hypothesis. Biology of Reproduction 22 73-106.

Evans ACO \& Fortune JE 1997 Selection of the dominant follicle in cattle occurs in the absence of differences in the expression of messenger ribonucleic acid for gonadotropin receptors. Endocrinology 138 2963-2971.

Feral C, LeGall S \& Leymarie P 1995 Angiotensin II modulates steroidogenesis in granulosa and theca in the rabbit ovary: its possible involvement in atresia. European Journal of Endocrinology 133 747-753.
Gallinat S, Busche S, Raizada MK \& Sumners C 2000 The angiotensin II type 2 receptor: an enigma with multiple variations. American Journal of Physiology. Endocrinology and Metabolism 278 E357-E374.

Gimbrone MA Jr \& Alexander RW 1975 Angiotensin II stimulation of prostaglandin production in cultured human vascular endothelium. Science 189 219-220.

Ginther OJ, Kastelic JP \& Knopf L 1989 Composition and characteristics of follicular waves during the bovine estrous cycle. Animal Reproduction Science 20 187-200.

Ginther OJ, Bergfelt DR, Beg MA, Meira C \& Kot K 2004 In vivo effects of an intrafollicular injection of insulin-like growth factor 1 on the mechanism of follicle deviation in Heifers and Mares. Biology of Reproduction 70 99-105.

Giometti IC, Bertagnolli AC, Ornes RC, da Costa LFS, Carambula SF, Reis AM, de Oliveira JFC, Emanuelli IP \& Gonçalves PBD 2005 Angiotensin II reverses the inhibitory action produced by theca cells on bovine oocyte nuclear maturation. Theriogenology 63 1014-1025.

Hayashi K, Miyamoto A, Berisha B, Kosmann MR, Okuda K \& Schams D 2000 Regulation of angiotensin II production and angiotensin receptors in microvascular endothelial cells from bovine corpus luteum. Biology of Reproduction 62 162-167.

Hernández J, Astudillo H \& Escalante B 2002 Angiotensin II stimulates cyclooxygenase-2 mRNA expression in renal tissue from rats with kidney failure. American Journal of Physiology. Renal Physiology 282 F592-F598.

Husain A, Bumpus FM, Silva PD \& Speth RC 1987 Localization of angiotensin II receptors in ovarian follicles and the identification of angiotensin II in rat ovaries. PNAS 84 2489-2493.

Kim MP, Zhou M \& Wahl LM 2005 Angiotensin II increases human monocyte matrix metalloproteinase-1 through the AT2 receptor and prostaglandin $E_{2}$ : implications for atherosclerotic plaque rupture. Journal of Leukocyte Biology 78 195-201.

Kot K, Gibbons JR \& Ginther OJ 1995 A technique for intrafollicular injection in cattle: effects of hCG. Theriogenology 44 41-50.

Kuji N, Sueoka K, Miyazaki T, Tanaka M, Oda T, Kobayashi T \& Yoshimura Y 1996 Involvement of angiotensin II in the process of gonadotropininduced ovulation in rabbits. Biology of Reproduction 55 984-991.

Nielsen AH, Hagemann A, Svenstrup B, Nielsen J \& Poulsen K 1994 Angiotensin-II receptor density in bovine ovarian follicles relates to tissue renin and follicular size. Clinical and Experimental Pharmacology and Physiology 21 463-469.

Pellicer A, Palumbo A, DeCherney AH \& Naftolin F 1988 Blockage of ovulation by an angiotensin antagonist. Science 240 1660-1661.

Peters MW, Pursley JR \& Smith GW 2004 Inhibition of intrafollicular PGE 2 synthesis and ovulation following ultrasound-mediated intrafollicular injection of the selective cyclooxygenase-2 inhibitor NS-398 in cattle. Journal of Animal Science 82 1656-1662.

Portela VV, Gonçalves PBD, Buratini J Jr, Price CA 2006 A novel role for angiotensin II in the regulation of protease-nexin-1 expression and secretion in bovine follicles. Proceedings of the Society for the Study of Reproduction, 39th Annual Meeting, Omaha, NE, USA. Pages 172-173.

Portela VV, Gonçalves PBD, Veiga AM, Nicola E, Zamberlam GO \& Price CA 2007 Regulation of angiotensin type 2 receptor in bovine granulosa cells in vitro. Proceedings of the Society for the Study of Reproduction, 40th Annual Meeting, San Antonio, TX, USA. Page 121.

Robker RL, Russell DL, Yoshioka S, Sharma SC, Lydon JP, Malley BW, Espey LL \& Richards JS 2000 Ovulation: a multi-gene, multi-step process. Steroids 65 559-570.

Sartori R, Fricke PM, Ferreira JCP, Ginther OJ \& Wiltbank MC 2001 Follicular deviation and acquisition of ovulatory capacity in bovine follicles. Biology of Reproduction 65 1403-1409.

Savio JD, Keenan L, Boland MP \& Roche JF 1988 Pattern of growth of dominant follicles during the oestrous cycle of heifers. Journal of Reproduction and Fertility 83 663-671.

Schauser KH, Nielsen AH, Winther H, Dantzer V \& Poulsen K 2001 Localization of the renin-angiotensin system in the bovine ovary: cyclic variation of the angiotensin II receptor expression. Biology of Reproduction 65 1672-1680.

Scheuren N, Jacobs M, Ertl G \& Schorb W 2002 Cyclooxygenase-2 in myocardium stimulation by angiotensin-II in cultured cardiac fibroblasts and role at acute myocardial infarction. Journal of Molecular and Cellular Cardiology 34 29-37. 
Sirois J 1994 Induction of prostaglandin endoperoxide synthase-2 by human chorionic gonadotropin in bovine preovulatory follicles in vivo. Endocrinology 135 841-848.

Sirois J \& Dore M 1997 The late induction of prostaglandin G/H synthase-2 in equine preovulatory follicles supports its role as a determinant of the ovulatory process. Endocrinology 138 4427-4434.

Stefanello JR, Barreta MH, Porciuncula PM, Arruda JN, Oliveira JF, Oliveira MA \& Gonçalves PBD 2006 Effect of angiotensin II with follicle cells and insulin-like growth factor-I or insulin on bovine oocyte maturation and embryo development. Theriogenology 66 2068-2076.

Tanaka M, Ohnishi J, Ozawa Y, Sugimoto M, Usuki S, Naruse M Murakami K \& Miyazaki H 1995 Characterization of angiotensin II receptor type 2 during differentiation and apoptosis of rat ovarian cultured granulosa cells. Biochemical and Biophysical Research Communications 207 593-598.

Whitebread S, Mele M, Kamber B \& DeGasparo M 1989 Preliminary biochemical characterization of two angiotensin II receptor subtypes. Biochemical and Biophysical Research Communications 163 284-291.

Yamada T, Horiuchi M \& Dzau VJ 1996 Angiotensin type 2 II receptor mediates programmed cell death. PNAS 93 156-160.
Yoshimura Y, Karube M, Koyama N, Shiokawa S, Nanno T \& Nakamura Y 1992 Angiotensin II directly induces follicle rupture and oocyte maturation in the rabbit. FEBS Letters 307 305-308.

Yoshimura Y, Karube M, Oda T, Koyama N, Shiokawa S, Akiba M, Yoshinaga A \& Nakamura Y 1993 Locally produced angiotensin II induces ovulation by stimulating prostaglandin production in in vitro perfused rabbit ovaries. Endocrinology 133 1609-1616.

Yoshimura Y, Koyama N, Karube M, Oda T, Akiba M, Yoshinaga A, Shiokawa S, Jinno M \& Nakamura Y 1994 Gonadotropin stimulates ovarian renin-angiotensin system in the rabbit. Journal of Clinical Investigation 93 180-187.

Yoshimura Y, Karube M, Aoki H, Oda T, Koyama N, Nagai A, Akimoto Y, Hirano H \& Nakamura Y 1996 Angiotensin II induces ovulation and oocyte maturation in rabbit ovaries via the AT2 receptor subtype. Endocrinology 137 1204-1211.

Received 23 May 2007

First decision 10 July 2007

Accepted 8 August 2007 